\title{
Prior Publication
}

(in whole or in substantial part)

"Narrative Reflections: Re-envisaging the Poet in The Canterbury Tales and The Faerie Queene," in Refiguring Chaucer in the Renaissance, ed. Theresa M. Krier (Gainesville: University Press of Florida, I998), 87-I05: now entitled "Chaucer's and Spenser's Reflexive Narrators."

"What Comes after Chaucer's But: Adversative Constructions in Spenser," in Acts of Interpretation: The Text in Its Contexts, ed. Mary J. Carruthers and Elizabeth D. Kirk (Norman, Okla.: Pilgrim, I982), I05-I8: now entitled "What Comes after Chaucer's But in The Faerie Queene."

" 'A Gentle Knight was pricking on the plaine': The Chaucerian Connection," English Literary Renaissance, I5 (I985), I66-74: now entitled " 'Pricking on the plaine': Spenser's Intertextual Beginnings and Endings" (C) Blackwell/Wiley).

“Allegory, Irony, Despair: Chaucer's Pardoner's and Franklin's Tales and Spenser's Faerie Queene, Books I and III," in Textual Conversations in the Renaissance: Ethics, Authors, and Technologies, ed. Zachary Lesser and Benedict Robinson (Aldershot, Hampshire, U.K.: Ashgate, 2006), 7I-89.

“'Myn auctour': Spenser's Enabling Fiction and Eumnestes' 'immortall scrine," " in Unfolded Tales: Studies in Renaissance Romance, ed. George M. Logan and Gordon Teskey (Ithaca, N.Y.: Cornell University Press, I989), I6-3I: now entitled "Eumnestes' 'immortall scrine': Spenser's Archive."

"Prudence and Her Silence: Spenser's Use of Chaucer's Melibee," ELH, 62 (I995), 29-46: now entitled "Spenser's Use of Chaucer's Melibee: Allegory, Narrative, History" ( Johns Hopkins University Press).

“" 'Nat worth a boterflye': Muiopotmos and The Nun's Priest's Tale," Journal of Medieval and Renaissance Studies, I (I97I), 89-I06: now entitled "Spenser's Muiopotmos and Chaucer's Nun's Priest's Tale" (C) Duke University Press).

"Arthur, Argante, and the Ideal Vision: An Exercise in Speculation and Parody," in The Passing of Arthur: New Essays in Arthurian Tradition, ed. 
Christopher Baswell and William Sharpe (New York: Garland, I988), I93-206: now entitled "Arthur and Argante: Parodying the Ideal Vision" (C) Routledge/Taylor and Francis).

“"The 'couert vele': Chaucer, Spenser, and Venus," English Literary Renaissance, 24 (1994), 638-59: now entitled "Chaucer's Parliament of Fowls and Refractions of a Veiled Venus in The Faerie Queene" (ㄷ Blackwell/ Wiley).

“The Antiquities of Fairyland and Ireland," JEGP, 86 (I987), I99-2 I4 (C) University of Illinois Press).

"Better a mischief than an inconvenience: 'The saiyng self' in Spenser's View, or, How many meanings can stand on the head of a proverb?" in Worldmaking Spenser: Explorations in the Early Modern Age, ed. Patrick Cheney and Lauren Silberman (Lexington: University of Kentucky Press, I999), 219-33: now entitled "Better a mischief than an inconvenience: "The saiyng self' in Spenser's View of the Present State of Ireland."

"The Conspiracy of Realism: Impasse and Vision in King Lear," Studies in Philology, 84 (1987), I-23: now entitled "The Conspiracy of Realism: Impasse and Vision in The Faerie Queene and Shakespeare's King Lear" (C) University of North Carolina Press).

"Venus and Adonis: Spenser, Shakespeare, and the Forms of Desire," in Grief and Gender, 700-1700, ed. Jennifer C. Vaught, with Lynne Dickson Bruckner (New York: Palgrave Macmillan, 2003), I49-60.

"Flowers and Boars: Surmounting Sexual Binarism in Spenser's Garden of Adonis," Spenser Studies, 23 (forthcoming 2008, (C) AMS Press).

"Acrasian Fantasies: Outsides, Insides, Upsides, Downsides in the Bower of Bliss," in A Touch More Rare: Harry Berger, Jr., and the Arts of Interpretation, ed. David Lee Miller and Nina Levine (New York: Fordham University Press, forthcoming 2009): now entitled "Androcentrism and Acrasian Fantasies in the Bower of Bliss."

"Beyond Binarism: Eros/Death and Venus/Mars in Shakespeare's Antony and Cleopatra and Spenser's Faerie Queene," in Shakespeare and Spenser: Attractive Opposites, ed. J. B. Lethbridge (Manchester, U.K.: Manchester University Press, forthcoming 2008).

"Passion and Patience in Shakespeare and Milton," Spenser Studies, 2 I (2007), 2005-20 (C AMS Press).

Each essay appears herein with the permission of the original publisher and holder of copyright, the latter identical with the publisher unless otherwise indicated. 
READING THE

A L LEGORICAL IN TERTEXT 
This page intentionally left blank 